\title{
The Effect of Soaking Seed with Rizobacteria Pseudomonas Alcaligenes to the Growth of Swamp Cabbage Ipomoea Reptans Poir
}

\author{
I Ketut Widnyana*, Maksimus Ngga, and Putu Lasmi Yuliyanthi Sapanca \\ Laboratory of Agro Technology, University of Mahasaraswati, India
}

Submission: February 15, 2017; Published: April 25, 2017

"Corresponding author: I Ketut Widnyana, Laboratory of Agro Technology Faculty of Agriculture, University of Mahasaraswati, India, Email: widnyanaketut@gmail.com

\begin{abstract}
Research of "The effect of soaking seeds with the bacteria Pseudomonas alcaligenes to the growth of swamp cabbage (Ipomoea reptans Poir)" was conducted to determine the effect of seed soaking with suspense of P. alcaligenes isolate KtS1, TrN2 and TmA1 to the growth of swamp cabbage. This research is the development of research that has been done before on tomato plants. This study was designed with a Randomized Block Design and data analysis using SPSS v.17 for windows. The treatments were three types of isolates of P. alcaligenes, soaking time, and growing medium. The parameters observed were germination and other growth parameters. The results showed that seed soaking treatment with suspense P. alcaligenes cause germination $25 \%$ faster, higher crop up $24.4 \%$, number of leaves more up to $23.15 \%$, longer stems to $25 \%$, longer roots up $46.90 \%$, fresh stem weight higher up to $67.07 \%$, dry weight oven stem higher up $84.21 \%$ if compared with control. The best treatment response was $\operatorname{TrN} 2.6 \mathrm{NB}$, soaking seeds of swamp cabbage with P. alcaligenes TrN2 for 60 minutes on medium NB (Natrium broth).
\end{abstract}

Keywords: Seed soaking; Pseudomonas alcaligenes; Rizobacteria; Swamp cabbage

\section{Introduction}

Swamp cabbage (Ipomoea reptans Poir) is a vegetable that has economic value and widespread in Southeast Asia. Swamp cabbage is generally consumed by the people of Indonesia and can be one of the restaurant's menu [1]. Swamp cabbage is a plant that is relatively resistant to drought and has a broad adaptability to various environmental conditions plants, easy maintenance and has a short harvest period [2]. Swamp cabbage commonly grown in home gardens and some small intensively planted on dry land, so as to optimize the production of swamp is still lacking. Swamp cabbage contains complete nutrition, including protein, fat, carbohydrates, fiber, calcium, phosphorus, iron, sodium, potassium, vitamin A,B,C, and carotenoids [3]. Additionally, swamp cabbage serves as medicinal plants to cure constipation, soothe the nerves and the drug hemorrhoids [4]. Swamp cabbage production in Indonesia can reach 50.000-60.000 kg ha-1 [5]. Cultivated Swamp cabbage for 0.10 ha spent $16 \mathrm{~kg}$ of seed planting swamp cabbage however slightly results are compared with other crops [6]. From the social and economic aspects, swamp has good prospects if developed towards agribusiness, but it does require effort in planting efficiency.
The use rizobacteria (Plant Growth Promoting Rhizobacteria (PGPR)) as a biological fertilizer is the contribution of biotechnology in crop productivity improvement efforts. This was achieved by nutrient mobilization, growth hormone production, nitrogen fixation or activation of the mechanism of disease resistance $[7,8]$. Therefore, the evaluation of the ability of local Rizobacteria as bacterial growth driver needs to be done. If proven effective, the local Rizobacteria can be used as an alternative biological fertilizer (biofertilizer) on the cultivation of swamp cabbage in Indonesia. Efforts to reduce the use of synthetic fertilizers and pesticides are needed in moving towards environmentally sustainable agriculture. Lately, attention has focused on biological resources in improving health (resistance) of plants, through the role of beneficial soil microbes. Microbes that are beneficial to plants, such as Pseudomonas spp of the rizobacteria group can serve as fertilizer, as a means of biological control of plant pathogens and improve plant resistance (induced systemic resistance (ISR) [9].

Rizobacteria is a group of bacteria with the plant root zone habitat (rizosphere) which has been researched and proven to 
improve soil fertility, increase plant resistance and can suppress plant pathogens. Rizobacteria act directly as a biological fertilizer and biological stimulants to produce hormones to grow crops such as IAA (indole acetic acid), gibberilin, cytokinin, ethylene, dissolving minerals and indirectly also serves to prevent pathogenic microorganisms through formation of siderophore, and antibiotics. Besides, it can stimulate plant growth mechanism is not widely known [9]. One of the Rizobacteria already been investigated as PGPR and ISR is P. alcaligenes isolate KtS1, TrN2 and TmA1 has been shown to increase the growth and yield of tomatoes [10]. The issues examined are how will soak the seeds with P. alcaligenes suspense to the growth of swamp cabage and how best to seed soaking time in promoting the growth of swamp cabage, with the purpose of obtaining information related to the benefits of soaking seeds of swamp cabage and best soaking time for swamp cabage growth.

\section{Materials and Methods}

\section{Research design}

This Research was designed using Randomized Block Design (RBD) with seed soaking treatment use suspense of P. alcaligenes isolates KtS1, TrN2, and TmA1 and using two different media which Dextrosa Potato Broth (PDB) and Natrium Broth (NB), respectively soaked 20,40, 60 minutes so there are 18 units plus one control treatment. Thus there are 19 types of treatment were repeated 3 times so that there are 57 experimental units. The 19 types of treatment are as presented in Table 1.

Table 1: Type of treatment observed in their effects on growth of the swamp cabbage.

\begin{tabular}{|c|c|c|}
\hline Number & Code & Treatment \\
\hline 1 & Control & Soaking seed with sterilized watter \\
\hline 2 & TmA1.2PDB & Soaking seed with $P$. alcaligenes TmA1 20 minute on PDB medium \\
\hline 3 & TmA1.2NB & Soaking seed with $P$. alcaligenes TmA1 20 minute on NB medium \\
\hline 4 & TmA1.4PDB & Soaking seed with $P$. alcaligenes TmA1 30 minute on PDB medium \\
\hline 5 & TmA1.4NB & Soaking seed with $P$. alcaligenes TmA1 30 minute on NB medium \\
\hline 6 & TmA1.6PDB & Soaking seed with $P$. alcaligenes TmA1 60 minute on PDB medium \\
\hline 7 & TmA1.6NB & Soaking seed withP. alcaligenes TmA1 60 minute on NB medium \\
\hline 8 & $\mathrm{KtS1.2PDB}$ & Soaking seed with $P$. alcaligenes KtS1 20 minute on PDB medium \\
\hline 9 & KtS1.2NB & Soaking seed with P. alcaligenes KtS1 20 minute on NB medium \\
\hline 10 & KtS1.4PDB & Soaking seed with $P$. alcaligenes KtS1 30 minute on PDB medium \\
\hline 11 & $\mathrm{KtS1.4NB}$ & Soaking seed with $P$. alcaligenes KtS1 30 minute on NB medium \\
\hline 12 & KtS1.6PDB & Soaking seed with $P$. alcaligenesKtS1 60 minute on PDB medium \\
\hline 13 & KtS1.6NB & Soaking seed with $P$. alcaligenes KtS1 60 minute on NB medium \\
\hline 14 & TrN2.2PDB & Soaking seed with P. alcaligenes TrN2 20 minute on PDB medium \\
\hline 15 & TrN2.2NB & Soaking seed with $P$. alcaligenes TrN2 20 minute on NB medium \\
\hline 16 & TrN2.4PDB & Soaking seed with P. alcaligenes TrN2 30 minute on PDB medium \\
\hline 17 & TrN2.4NB & Soaking seed with P. alcaligenes TrN2 30 minute on NB medium \\
\hline 18 & TrN2.6PDB & Soaking seed with P. alcaligenes TrN2 60 minute on PDB medium \\
\hline 19 & TrN2.6NB & Soaking seed with $P$. alcaligenes $\operatorname{TrN} 260$ menit pada NB medium \\
\hline
\end{tabular}

\section{Preparation isolate the bacteria P. Alcaligenes}

Isolates of $P$. alcaligenes obtained in the laboratory of Agro Technology Faculty of Agriculture, University Mahasaraswati Denpasar previously been investigated its effect on tomato plants and have been identified as P. alcaligenes KtS1, P. alcaligenes TrN2 and P. alcaligenes TmA1 [10]. The suspension isolates of P. alcaligenes isolated on PDP and NB media and cultured for 48 hours in a $100 \mathrm{ml}$ Erlenmeyer to get a colony density of $5 \times 10^{8} \mathrm{cfu} / \mathrm{ml}$.

\section{Planting swamp cabbage}

Planting seeds of swamp cabbage that had been treated with P. alcaligenes into polybag that already filled sterile planting medium (mixture of soil, sand and organic fertilizer with a ratio of 1:2:1). Planting is done by 2 units swamp cabbage seeds that have been soaked in suspense P. alcaligenes according to treatment in a polybag. Polybag then placed with a distance of $10 \mathrm{~cm} \times 10 \mathrm{~cm}$. Watering every morning and afternoon with a volume of $100 \mathrm{ml}$ for each polybag.

\section{Parameter observation and data analysis}

Observation on the germination of seeds is done daily until sprouts appear, for plant height, leaf number, leaf blade length was measured once a week. Root length was measured at harvest. Besides, do also measuring the fresh weight and oven dry weight of the roots and stems of plants swamp cabbage. Data analysis was performed with SPSS v.17 for windows and different test performed on average by Duncans Multiple Rings Test (DMRT) at the level of $5 \%$. 


\section{Results and Discussion}

\section{Germination of seeds, plant high, long leaf and leaf number swamp cabbage}

Table 2: Effect of seed soaking with the bacteria P. alcaligenes TrN2, KtS1, and TmA1 on seed germination, plant height, leaf number and length leaf of swamp cabbage.

\begin{tabular}{|c|c|c|c|c|c|}
\hline \multirow[b]{2}{*}{ No } & \multirow[b]{2}{*}{ Treatment } & \multicolumn{4}{|c|}{ Average Results of Observations on the Parameters of Swamp Cabbage } \\
\hline & & $\begin{array}{c}\text { Speed of Germination } \\
\text { (Days) }\end{array}$ & Plant Height (cm) & $\begin{array}{c}\text { Number of Leaves } \\
\text { (Sheet) }\end{array}$ & Leaf Length $(\mathrm{cm})$ \\
\hline & Leaf Length $(\mathrm{cm})$ & & & & \\
\hline 1 & CONTROL & $3.75 \mathrm{ab}$ & $20.9 \mathrm{~ns}$ & $10.8 \mathrm{~ns}$ & $8.3 \mathrm{~ns}$ \\
\hline 2 & TmA1.2 PDB & $3.00 \mathrm{~b}$ & $22.9 \mathrm{~ns}$ & $11.8 \mathrm{~ns}$ & $9.2 \mathrm{~ns}$ \\
\hline 3 & TmA1.2 NB & $3.00 \mathrm{~b}$ & $22.6 \mathrm{~ns}$ & $11.8 \mathrm{~ns}$ & $8.9 \mathrm{~ns}$ \\
\hline 4 & TmA1.4 PDB & $3.25 \mathrm{ab}$ & $21.8 \mathrm{~ns}$ & $12.3 \mathrm{~ns}$ & $8.7 \mathrm{~ns}$ \\
\hline 5 & TmA1.4 NB & $3.50 \mathrm{ab}$ & $24.0 \mathrm{~ns}$ & $11.8 \mathrm{~ns}$ & $9.6 \mathrm{~ns}$ \\
\hline 6 & TmA1.6 PDB & $4.50 \mathrm{ab}$ & $23.8 \mathrm{~ns}$ & $11.8 \mathrm{~ns}$ & $9.6 \mathrm{~ns}$ \\
\hline 7 & TmA1.6 NB & $4.50 \mathrm{ab}$ & $24.8 \mathrm{~ns}$ & $11.8 \mathrm{~ns}$ & $9.0 \mathrm{~ns}$ \\
\hline 8 & KtS1. 2 PDB & $3.75 \mathrm{ab}$ & $22.9 \mathrm{~ns}$ & $11.3 \mathrm{~ns}$ & $8.3 \mathrm{~ns}$ \\
\hline 9 & KtS1. 2 NB & $4.25 \mathrm{ab}$ & $22.6 \mathrm{~ns}$ & $10.8 \mathrm{~ns}$ & $8.6 \mathrm{~ns}$ \\
\hline 10 & KtS1. 4 PDB & $3.75 \mathrm{ab}$ & $21.8 \mathrm{~ns}$ & $11.5 \mathrm{~ns}$ & $8.9 \mathrm{~ns}$ \\
\hline 11 & KtS1. 4 NB & $3.75 \mathrm{ab}$ & $21.8 \mathrm{~ns}$ & $11.5 \mathrm{~ns}$ & $8.5 \mathrm{~ns}$ \\
\hline 12 & KtS1. 6 PDB & $4.00 \mathrm{ab}$ & $21.0 \mathrm{~ns}$ & $10.3 \mathrm{~ns}$ & $8.4 \mathrm{~ns}$ \\
\hline 13 & KtS1. 6 NB & $4.75 \mathrm{ab}$ & $24.0 \mathrm{~ns}$ & $11.3 \mathrm{~ns}$ & $9.5 \mathrm{~ns}$ \\
\hline 14 & TrN2. 2 PDB & $3.50 \mathrm{ab}$ & $21.6 \mathrm{~ns}$ & $11.8 \mathrm{~ns}$ & $8.6 \mathrm{~ns}$ \\
\hline 15 & TrN2. 2 NB & $3.50 \mathrm{ab}$ & $22.8 \mathrm{~ns}$ & $13.0 \mathrm{~ns}$ & $9.1 \mathrm{~ns}$ \\
\hline 16 & TrN2. 4 PDB & $4.25 \mathrm{ab}$ & $23.3 \mathrm{~ns}$ & $13.3 \mathrm{~ns}$ & $9.6 \mathrm{~ns}$ \\
\hline 17 & TrN2. 4 NB & $3.25 \mathrm{ab}$ & $26.0 \mathrm{~ns}$ & $13.3 \mathrm{~ns}$ & $10.3 \mathrm{~ns}$ \\
\hline 18 & TrN2. 6 PDB & $4.00 \mathrm{ab}$ & $24.1 \mathrm{~ns}$ & $11.5 \mathrm{~ns}$ & $9.3 \mathrm{~ns}$ \\
\hline 19 & TrN2. 6 NB & $4.00 \mathrm{ab}$ & $25.0 \mathrm{~ns}$ & $12.8 \mathrm{~ns}$ & $9.8 \mathrm{~ns}$ \\
\hline
\end{tabular}

Note: The same letters behind the numbers in the same column shows the difference was not significant at the 0.05 level of DMRT.

Statistical analysis shows that the effect of seed soaking treatment with the bacteria P. alcaligenes TrN2, KtS1, TmA1 not significant effect on plant height, leaf length and number of leaves of swamp cabbage, detailed results of the analysis are presented in Table 2.

Data shown in Table 2 show that soaking seeds with $\mathrm{P}$. alcaligenes $\mathrm{TrN} 2, \mathrm{KtS} 1$, and $\mathrm{TmA} 1$ with different soaking time showed a significant effect on the speed of seed germination. Seeds germinate fastest found on TmA1.2PDB and TmA1.2NB ie on 3rd day, 0.75 days faster than the control (3.75days). This is in accordance statement Widnyana \& Javandira [11]. Which states that based on the observations of the length of time soaking of tomato plants with a bacterial suspension of Pseudomonas sp. and Bacillus $s p$. give a good effect. Soaking seeds of tomato plants with a bacterial suspension of Pseudomonas spp and Bacillus sp. for 10 minutes and 20 minutes gave the influence of tomato seedlings grown in the seeding of the most well compared with other treatments and control the same namely $87.50 \%$. Swamp cabbage highest in TrN2.4NB treatment is $26.0 \mathrm{~cm}$, followed by TrN2. $6 \mathrm{NB}$ is $25.0 \mathrm{~cm}$, higher $24.4 \%$ and $19.6 \%$ compared control $(20.9 \mathrm{~cm})$. Highest number of leaves found on TrN2.4PDB treatment and TrN2.4NB respectively 13.3 pieces, followed by treatment $\operatorname{TrN} 2$. $2 \mathrm{NB}$ as 13 pieces. This amount is more $23.15 \%$ and $20.37 \%$ compared with control (10.8 pieces). The longest leaves are on treatment $\operatorname{TrN} 2.4 \mathrm{NB}$ is $10.3 \mathrm{~cm}$, followed by treatment $\operatorname{TrN} 2.6 \mathrm{NB}$ is $9.8 \mathrm{~cm}$. This leaves a longer $24.10 \%$ and $15.31 \%$ of the control $(8.3 \mathrm{~cm})$. These results are consistent with results of previous studies that the treatment of Pseudomonas spp. can promote the growth of tobacco plants with up to $14 \%$ [12].

\section{The length of the stem and stem fresh weight, length and fresh weight root swamp cabbage}

Statistical analysis showed that the treatment effect of soaking seeds with the bacteria P. alcaligenes TrN2, KtS1, and TmA1 not significant $(\mathrm{P} \geq 0.05)$ to the length of the stem and stem fresh weight, as well as length and fresh weight root swamp cabbage, details are presented in Table 3.

Table 3 shows the longest swamp cabbage stem found in TmA1.2PDB is $26.0 \mathrm{~cm}$, followed by $\operatorname{TrN} 2.6 \mathrm{NB}$ is $25.8 \mathrm{~cm}$, both longer $25 \%$ and $24.04 \%$ of the control $(20.8 \mathrm{~cm})$. The longest roots found in TmA1.6NB is followed by TrN2.6NB $21.3 \mathrm{~cm}$ to $18.3 \mathrm{~cm}$. The 
roots in both the treatment is longer $46.90 \%$ and $26.21 \%$ compared with control $(14.5 \mathrm{~cm})$. The fresh weight stem highest in TrN2. 6NB is $2795 \mathrm{~g}$, followed by TrN2. $4 \mathrm{NB}$ is $2.495 \mathrm{~g}$. The fresh weight stem in both treatments was higher $67.07 \%$ and $49.13 \%$ compared with control $(1,673 \mathrm{~g})$. Weight of fresh roots that is highest in the treatment TrN2.6NB is $0.788 \mathrm{~g}$, followed by treatment TmA1.6NB is $0.663 \mathrm{~g}$. The fresh weight root on both treatments is higher $93.14 \%$ and $62.50 \%$ compared with the control $(0408 \mathrm{~g})$.

Table 3: Effect of soaking seeds with the bacteria P. alcaligenes. TrN2, KtS1, and TmA1 on stem length, root length, fresh weight, and root fresh weight of swamp cabbage.

\begin{tabular}{|c|c|c|c|c|c|}
\hline \multirow[b]{2}{*}{ No } & \multirow[b]{2}{*}{ Treatment } & \multicolumn{4}{|c|}{ Average results of observations on the parameters of swamp cabbage } \\
\hline & & Stem Length (cm) & Root Length (cm) & $\begin{array}{l}\text { Stem Fresh Weight } \\
\text { (g) }\end{array}$ & $\begin{array}{l}\text { Root Fresh Weight } \\
\text { (g) }\end{array}$ \\
\hline 1 & Control & $20.8 \mathrm{~ns}$ & $14.5 \mathrm{~ns}$ & $1.673 \mathrm{~ns}$ & $0.408 \mathrm{~ns}$ \\
\hline 2 & TmA1.2 PDB & $26.0 \mathrm{~ns}$ & $15.3 \mathrm{~ns}$ & $2.175 \mathrm{~ns}$ & $0.483 \mathrm{~ns}$ \\
\hline 3 & TmA1.2 NB & $23.5 \mathrm{~ns}$ & $12.5 \mathrm{~ns}$ & $1.988 \mathrm{~ns}$ & $0.513 \mathrm{~ns}$ \\
\hline 4 & TmA1.4 PDB & $23.0 \mathrm{~ns}$ & $14.8 \mathrm{~ns}$ & $2.120 \mathrm{~ns}$ & $0.485 \mathrm{~ns}$ \\
\hline 5 & TmA1.4 NB & $23.3 \mathrm{~ns}$ & $12.8 \mathrm{~ns}$ & $1.990 \mathrm{~ns}$ & $0.410 \mathrm{~ns}$ \\
\hline 6 & TmA1.6 PDB & $25.5 \mathrm{~ns}$ & $14.5 \mathrm{~ns}$ & $2.168 \mathrm{~ns}$ & $0.465 \mathrm{~ns}$ \\
\hline 7 & TmA1.6 NB & $25.0 \mathrm{~ns}$ & $21.3 \mathrm{~ns}$ & $2.280 \mathrm{~ns}$ & $0.663 \mathrm{~ns}$ \\
\hline 8 & KtS1. 2 PDB & $22.5 \mathrm{~ns}$ & $13.0 \mathrm{~ns}$ & $1.670 \mathrm{~ns}$ & $0.420 \mathrm{~ns}$ \\
\hline 9 & KtS1. 2 NB & $21.5 \mathrm{~ns}$ & $16.0 \mathrm{~ns}$ & $1.718 \mathrm{~ns}$ & $0.418 \mathrm{~ns}$ \\
\hline 10 & KtS1. 4 PDB & $21.3 \mathrm{~ns}$ & $12.5 \mathrm{~ns}$ & $1.763 \mathrm{~ns}$ & $0.428 \mathrm{~ns}$ \\
\hline 11 & KtS1. 4 NB & $24.8 \mathrm{~ns}$ & $11.3 \mathrm{~ns}$ & $1.820 \mathrm{~ns}$ & $0.423 \mathrm{~ns}$ \\
\hline 12 & KtS1. 6 PDB & $22.5 \mathrm{~ns}$ & $12.5 \mathrm{~ns}$ & $1.748 \mathrm{~ns}$ & $0.338 \mathrm{~ns}$ \\
\hline 13 & KtS1. 6 NB & $24.3 \mathrm{~ns}$ & $13.5 \mathrm{~ns}$ & $2.240 \mathrm{~ns}$ & $0.493 \mathrm{~ns}$ \\
\hline 14 & TrN2. 2 PDB & $22.0 \mathrm{~ns}$ & $15.0 \mathrm{~ns}$ & $1.558 \mathrm{~ns}$ & $0.450 \mathrm{~ns}$ \\
\hline 15 & TrN2. 2 NB & $24.0 \mathrm{~ns}$ & $12.5 \mathrm{~ns}$ & $2.038 \mathrm{~ns}$ & $0.430 \mathrm{~ns}$ \\
\hline 16 & TrN2. 4 PDB & $24.3 \mathrm{~ns}$ & $16.5 \mathrm{~ns}$ & $2.473 \mathrm{~ns}$ & $0.608 \mathrm{~ns}$ \\
\hline 17 & TrN2. 4 NB & $27.0 \mathrm{~ns}$ & $15.3 \mathrm{~ns}$ & $2.495 \mathrm{~ns}$ & $0.560 \mathrm{~ns}$ \\
\hline 18 & TrN2. 6 PDB & $25.0 \mathrm{~ns}$ & $13.0 \mathrm{~ns}$ & $1.905 \mathrm{~ns}$ & $0.533 \mathrm{~ns}$ \\
\hline 19 & TrN2. 6 NB & $25.8 \mathrm{~ns}$ & $18.3 \mathrm{~ns}$ & $2.795 \mathrm{~ns}$ & $0.788 \mathrm{~ns}$ \\
\hline
\end{tabular}

Note: The same letters behind the numbers in the same column shows the difference was not significant at the 0.05 level of DMRT.

The data indicate that treatment of soaking seeds with the bacteria P. alcaligenes give good influence in the growth of swamp cabbage, especially P. alcaligenes TrN2 that cause weight gain swamp cabbage stem up to $67.07 \%$. These results are consistent with the statement Gehardson [13] that the use of these Pseudomonas spp in plant roots can promote plant growth and protect plants from plant pathogens and pests. Rizobacteria Pseudomonas spp. have a positive effect by occupying the surface of plant root tissues and provides compounds that are beneficial to plants. Some of these bacteria entrance further into the tissue and become endofitik without causing damage or morphological changes in plants [14].

\section{Oven dry weight of plants, stems, and roots swamp cabbage}

Statistical analysis showed that the treatment effect of soaking seeds with the bacteria $P$. alcaligenes $\operatorname{TrN} 2$, KtS1, and TmA1 significant $(\mathrm{P} \leq 0.05)$ on oven dry weight of stem and root, the details are presented in Table 4.

Table 4 shows that the weight of oven dried swamp cabbage stem highest in TrN2.6NB is $0.35 \mathrm{~g}$, followed by TrN2. $4 \mathrm{NB}$ is $0.34 \mathrm{~g}$. Both of these treatments significantly different $(\mathrm{P}<0.05)$ with the control $(0.19 \mathrm{~g})$. Both of these treatments have the oven dry weight of stem is higher $84.21 \%$ and $78.95 \%$ compared to the control. Swamp cabbage root oven dry weight highest in TrN2.6NB is $0.10 \mathrm{~g}$ significantly different with KtS1.4NB and control, with roots oven dry weight $0.04 \mathrm{~g}$ respectively. Treatment TrN2.6NB has oven dry weight of $150 \%$ higher than the control.

Table 4: Effect of soaking seeds treatment with bacterial isolates of $P$. alcaligenes TrN2, KtS1, and TmA1 to the oven dry weight of stems, and roots swamp cabbage.

\begin{tabular}{|l|l|l|l|}
\hline \multirow{2}{*}{ No } & \multirow{3}{|c|}{$\begin{array}{l}\text { Average Results of Observations } \\
\text { on the Parameters of Swamp } \\
\text { Cabbage }\end{array}$} \\
\cline { 3 - 4 } & Treatment & $\begin{array}{l}\text { Oven dry } \\
\text { weight the } \\
\text { stem (g) }\end{array}$ & $\begin{array}{l}\text { Oven dry } \\
\text { weight of the } \\
\text { root (g) }\end{array}$ \\
\hline 1 & Control & $0.19 \mathrm{~cd}$ & $0.04 \mathrm{~b}$ \\
\hline 2 & TmA1.2 PDB & $0.26 \mathrm{abcd}$ & $0.07 \mathrm{ab}$ \\
\hline 3 & TmA1.2 NB & $0.22 \mathrm{bcd}$ & $0.07 \mathrm{ab}$ \\
\hline 4 & TmA1.4 PDB & $0.25 \mathrm{abcd}$ & $0.07 \mathrm{ab}$ \\
\hline 5 & TmA1.4 NB & $0.21 \mathrm{~cd}$ & $0.05 \mathrm{ab}$ \\
\hline 6 & TmA1.6 PDB & $0.23 \mathrm{abcd}$ & $0.07 \mathrm{ab}$ \\
\hline 7 & TmA1.6 NB & $0.26 \mathrm{abcd}$ & $0.09 \mathrm{ab}$ \\
\hline 8 & KtS1.2 PDB & $0.19 \mathrm{~cd}$ & $0.05 \mathrm{ab}$ \\
\hline
\end{tabular}




\begin{tabular}{|l|l|l|l|}
\hline 9 & KtS1.2 NB & $0.18 \mathrm{~d}$ & $0.06 \mathrm{ab}$ \\
\hline 10 & KtS1.4 PDB & $0.18 \mathrm{~d}$ & $0.06 \mathrm{ab}$ \\
\hline 11 & KtS1.4 NB & $0.18 \mathrm{~d}$ & $0.04 \mathrm{~b}$ \\
\hline 12 & KtS1.6 PDB & $0.19 \mathrm{~cd}$ & $0.05 \mathrm{ab}$ \\
\hline 13 & KtS1. 6 NB & $0.29 \mathrm{abcd}$ & $0.08 \mathrm{ab}$ \\
\hline 14 & TrN2.2 PDB & $0.19 \mathrm{~cd}$ & $0.06 \mathrm{ab}$ \\
\hline 15 & TrN2.2 NB & $0.25 \mathrm{abcd}$ & $0.06 \mathrm{ab}$ \\
\hline 16 & TrN2.4 PDB & $0.32 \mathrm{abc}$ & $0.09 \mathrm{ab}$ \\
\hline 17 & TrN2. 4 NB & $0.34 \mathrm{ab}$ & $0.09 \mathrm{ab}$ \\
\hline 18 & TrN2.6 PDB & $0.26 \mathrm{abcd}$ & $0.07 \mathrm{ab}$ \\
\hline 19 & TrN2.6 NB & $0.35 \mathrm{a}$ & $0.10 \mathrm{a}$ \\
\hline
\end{tabular}

Note: The same letters behind the numbers in the same column shows the difference was not significant at the 0.05 level of DMRT.

The oven dry weight stems and roots of swamp cabbage are highest in TrN2.6NB, as well as fresh weight swamp cabbage stems and roots is highest in TrN2.6NB treatment. This suggests that the bacterium P. alcaligenes TrN2 treatment by soaking the seed for 60 minutes at medium Natrium Broth (NB) gives the best effect on plant growth swamp cabbage. In fact, according to the data that is already displayed in Table $2 \& 3$, it can be said that even though the statistical analysis soaking treatment no significant effect compared to control, but on the value presented shows all seed soaking treatment with the bacteria P. alcaligenes TrN2, KtS1 and TmA1 give higher values than the control on all parameters of observation, such as seed germination, plant height, stem length and weight of plants, number and length of leaves, stems and roots fresh weight swamp cabbage. This is in accordance with the opinion of Tenuta [15], the mechanism of PGPR in improving the health of plants can occur through three ways, is:

i. Pressing the development of pest/disease (bioprotectant): has a direct influence on the plant against pests and diseases.

ii. Producing fitohormon (biostimulant): IAA (Indole Acetic Acid); cytokinins; giberellin; and inhibiting the production of ethylene: can increase the surface area of fine roots, and

iii. Improve the availability of nutrients for plants (biofertilizer). While according McMilan [16], several roles PGPR in promoting the growth of the plants:

a. Increase nitrogen fixation in legumes,

b. Increase the population of bacterial nitrogen-fixing more,

c. Increase the supply of other nutrients, such as phosphorus, sulfur, iron and copper,

d. The production of hormones,

e. Increase the population of beneficial fungi or bacteria,

f. Control of fungal pathogens,

g. Controlling bacteria pathogens, and

h. To control insect pests

\section{Conclusion}

Soaking the seed treatment by suspension of P. alcaligenes TrN2 for 60 minutes at medium Natrium Broth (NB) gives the best effect on plant growth swamp cabbage. All seed soaking treatment with the bacteria P. alcaligenes TrN2, KtS1 and TmA1 give higher values than the control on all parameters of observation, such as seed germination, plant height, stem length and weight of plants, number and length of leaves, stems and roots fresh weight swamp cabbage. The results showed that seed soaking treatment with suspense $P$. alcaligenes cause germination $25 \%$ faster, higher crop up $24.4 \%$, number of leaves more up to $23.15 \%$, longer stems to $25 \%$, longer roots up $46.90 \%$, fresh stem weight higher up to $67.07 \%$, dry weight oven stem higher up $84.21 \%$ if compared with control.

\section{Acknowledgement}

Thank submitted to the Directorate of Research and Community Service, the Minister of Research, Technology and Higher Education and the Dean of the Faculty of Agriculture, University Mahasraswati Denpasar.

\section{References}

1. Rukmana R (1994) Swamp cabbage planting (in bahasa). Publisher Canisius.

2. Suratman P, Setyawan AD (2000) Analysis of the diversity of the genus Ipomoea based on morphological characters. (in bahasa) Biodiversitas 1(2): 72-79.

3. Polii MGM (2009) Response swamp cabbage production (Ipomoea reptans Poir) against the time variation of chicken manure fertilizer (in bahasa). Soil Environment 1: 18-22.

4. Sawasemariai AM (2012) Plant Growth and Yield Response of Swamp cabbage (Iponema reptans Poir) Against Giving Fertilizer Indovit, Sentra Foliar And Indomess (in bahasa) Essay. Department of Agriculture, Faculty of Agriculture and Agricultural Technology, Universitas Negeri Papua, Monokwari, pp. 1-3.

5. Harjadi SS, Suketi dK (1999) Influence When the harvesting of Production and Quality Four varieties of swamp cabbage (Ipomoea reptans poir) (in bahasa). Bul Agr 17(1): 31-44.

6. Parni (2012) Paddy Farmers Changing the Vegetable Crops (in bahasa). Antara News.

7. Wei G, Kloepper JW, Tuzun S (1996) Induced of systemic resistance to cucumber diseases and increased plant growth-promoting rhizobacteria under field conditions. Phytopathol 86: 221-224.

8. Thakuria D, Talukdar NC, Goswami C, Hazarika S, Boro RS, et al. (2004) Characterization and screening of bacteria from rhizosphere of rice grown in acidic soils of Assam. Current Sci 86: 978-985.

9. Alabouvette RP, Lemanceau, Steinberg C (1996) Biological Control of Fusarium Wilts: Opportunities for Developing A Comercial Product.

10. Widnyana, IK, Suprapta DN, Sudana IM, Rai Maya Temaja IG (2013) Pseudomonas alcaligenes, Potential Antagonist Against Fusarium oxysporum f.sp. lycopersicum the Cause of Fusarium Wilt Disease on Tomato. Journal of Biology, Agriculture and Healthcare 3(7).

11. Widnyana IK, Javandira C (2015) Activities Pseudomonas spp. and Bacillus sp. to Stimulate Germination and Seedling Growth of Tomato Plants. Agricultural Science Procedia 9(2016): 419-423.

12. Widnyana, Ketut I (2011) Efforts to Obtain biocontrol agents Wilt Disease of Tomato Fusarium oxysporum f.sp lycopersici Through 
Exploration and Potential Test Isolate PGPR Pseudomonas spp. Journal Bumi Lestari Lingkungan Hidup 11(2): 265-276.

13. Gerhardson B (2002) Biological substitutes for pesticides. Trends Biotechnol 20: 338-343.

14. Rosenblueth ME, Martı́nez-Romero (2006) Bacterial endophytes and their interactions wit hosts. Mol. Plant-Microbe Interact 19(8): 827837.

This work is licensed under Creative Commons Attribution 4.0 License

DOI:_10.19080/ARTOAJ.2017.06.555679
15. Tenuta M (2004) Plant PGPR. Prosfects for increasing nutrient acquisition and disease kontrol. Department of soil science, University of Manitoba, Canada.

16. McMilan S (2007) Promoting Growth with PGPR. The Canadian Organic Grower, Canada.

\section{Your next submission with Juniper Publishers} will reach you the below assets

- Quality Editorial service

- Swift Peer Review

- Reprints availability

- E-prints Service

- Manuscript Podcast for convenient understanding

- Global attainment for your research

- Manuscript accessibility in different formats ( Pdf, E-pub, Full Text, Audio)

- Unceasing customer service

Track the below URL for one-step submission https://juniperpublishers.com/online-submission.php 